\title{
Vegetation and hydrology stratification as proxies to estimate methane emission from tidal marshes
}

\author{
R. Kyle Derby • Brian A. Needelman (iD) Ana A. Roden • J. Patrick Megonigal
}

Received: 3 February 2021 / Accepted: 14 October 2021 / Published online: 1 December 2021

(C) The Author(s) 2021

\begin{abstract}
Direct measurement of methane emissions is cost-prohibitive for greenhouse gas offset projects, necessitating the development of alternative accounting methods such as proxies. Salinity is a useful proxy for tidal marsh $\mathrm{CH}_{4}$ emissions when comparing across a wide range of salinity regimes but does not adequately explain variation in brackish and freshwater regimes, where variation in emissions is large. We sought to improve upon the salinity proxy in a marsh complex on Deal Island Peninsula, Maryland, USA by comparing emissions from four strata differing in hydrology and plant community composition. Mean $\mathrm{CH}_{4}$ chamber-collected emissions measured as $\mathrm{mg}$ $\mathrm{CH}_{4} \mathrm{~m}^{-2} \mathrm{~h}^{-1}$ ranked as $S$. alterniflora $(1.2 \pm 0.3) \gg$
\end{abstract}

Responsible Editor: Adam Langley.

R. K. Derby

University of Maryland, College Park, USA

e-mail: rkderby@gmail.com

B. A. Needelman $(\bowtie)$

University of Maryland, 1213 HJ Patterson Hall,

College Park, MD, USA

e-mail: bneed@umd.edu

A. A. Roden

University of Wisconsin, Madison, USA

e-mail: aroden@wisc.edu

J. P. Megonigal

Smithsonian Environmental Research Center, Maryland,

USA

e-mail: megonigalp@si.edu
High-elevation $J$. roemerianus $(0.4 \pm 0.06)>$ Lowelevation $J$. roemerianus $(0.3 \pm 0.07)=S$. patens $(0.1 \pm 0.01)$. Sulfate depletion generally reflected the same pattern with significantly greater depletion in the S. alterniflora stratum $(61 \pm 4 \%)$ than in the S. patens stratum $(1 \pm 9 \%)$ with the $J$. roemerianus strata falling in between. We attribute the high $\mathrm{CH}_{4}$ emissions in the S. alterniflora stratum to sulfate depletion likely driven by limited connectivity to tidal waters. Low $\mathrm{CH}_{4}$ emissions in the $S$. patens stratum are attributed to lower water levels, higher levels of ferric iron, and shallow rooting depth. Moderate $\mathrm{CH}_{4}$ emissions from the $J$. roemerianus strata were likely due to plant traits that favor $\mathrm{CH}_{4}$ oxidation over $\mathrm{CH}_{4}$ production. Hydrology and plant community composition have significant potential as proxies to estimate $\mathrm{CH}_{4}$ emissions at the site scale.

Keywords Wetland biogeochemistry · Blue carbon . Brackish tidal marshes - Methane emission accounting - Sulfate reduction · Iron reduction . Greenhouse gases · Carbon crediting

\section{Introduction}

Methane is a potent greenhouse gas produced under the dominantly anaerobic conditions found in wetland soils. The global warming potential of methane $\left(\mathrm{CH}_{4}\right)$ 
gas is 32-45 times greater than an equivalent amount of carbon dioxide $\left(\mathrm{CO}_{2}\right)$ over a 100 -year period (Neubauer and Megonigal 2015). While the majority of $\mathrm{CH}_{4}$ emissions come from anthropogenic sources, wetlands produce most of the naturally emitted $\mathrm{CH}_{4}$ (Wang et al. 1996; Solomon et al. 2007) and are the most important source of uncertainty in current global $\mathrm{CH}_{4}$ budgets (Saunois et al. 2020). Coastal wetland $\mathrm{CH}_{4}$ emissions were recently estimated at 5.3-6.2 Tg $\mathrm{CH}_{4}$ year ${ }^{-1}$, amounting to $60 \%$ of the global marine $\mathrm{CH}_{4}$ budget (Al-Haj and Fulweiler 2020), and $<7 \%$ of the global wetland $\mathrm{CH}_{4}$ budget (Saunois et al. 2020). Methane emissions are the largest source of uncertainty in the coastal wetland greenhouse gas budget (Holmquist et al. 2018). There is emerging interest in using tidal marsh restoration and conservation to mitigate greenhouse gases in the atmosphere and as a source of carbon credits (Crooks et al. 2011; Emmer et al. 2015a, b; Needelman et al. 2018; Emmer et al. 2020a,b), but the high carbon sequestration rates characteristic of tidal wetlands soils (Chmura et al. 2003; Nahlik and Fennesy 2016) can be partly or completely offset by $\mathrm{CH}_{4}$ emissions (Poffenbarger et al. 2011). The uncertainty introduced to greenhouse gas offset activities by $\mathrm{CH}_{4}$ emissions is especially large for coastal wetlands ecosystems with freshwaterto-brackish salinity $<18$ ppt (Poffenbarger et al. 2011). The sources of this variability remain elusive as there has been relatively little research designed to partition variation. Direct monitoring of methane emissions is cost-prohibitive for most blue carbon crediting projects (Needelman et al. 2018), creating a need for a better understanding of the factors that regulate coastal wetland $\mathrm{CH}_{4}$ emissions to create alternative estimation methods such as proxies and models.

Methane is produced in wetlands by methanogenic archaea. The production of $\mathrm{CH}_{4}$ occurs when there is an excess of electron donors over electron acceptors, depleting the availability of alternative electron acceptors such as ferric iron (Fe(III)) and sulfate $\left(\mathrm{SO}_{4}{ }^{2-}\right)$ (Megonigal et al. 2004). Electron donors are produced from labile organic materials that undergo fermentation to low molecular weight carbon compounds and $\mathrm{H}_{2}$. Electron donors can be present in the soil (e.g. Fe(III)), supplied from external sources such as floodwater (e.g. $\mathrm{SO}_{4}{ }^{2-}$ ), or provided by plants (e.g. molecular oxygen or oxidized compounds generated by radial oxygen loss). The availability of $\mathrm{SO}_{4}{ }^{2-}$ from seawater suppresses $\mathrm{CH}_{4}$ emissions from polyhaline (salinity $>18 \mathrm{ppt}$ ) marshes to consistently low rates (0.2 to $5.7 \mathrm{~g} \mathrm{CH}_{4} \mathrm{~m}^{-2}$ year $^{-1}$ ) (Poffenbarger et al. 2011), although high emission rates have been observed in polyhaline wetlands with high anthropogenic inputs (Purvaja and Ramesh 2001) and low $\mathrm{SO}_{4}{ }^{2-}$ replenishment due to restricted tidal exchange (Emery and Fulweiler 2017). Methane emissions from mesohaline brackish systems (5-18 ppt salinity) are greater and more variable (3.3 to $32.0 \mathrm{~g} \mathrm{CH}_{4} \mathrm{~m}^{-2}$ year $\left.^{-1}\right)$. Methanogenesis is also regulated by such physiochemical factors as $\mathrm{pH}$ (Walker et al. 1998; Garcia et al. 2000) and temperature (Megonigal and Schlesinger 2002; Whalen 2005).

Differences in methane emissions between dominant vegetation communities have been observed in tidal marsh systems such as Phragmites australis versus S. alterniflora (Yuan et al. 2015), P. australis versus mixed and native zones (Mueller et al. 2016) and $S$. patens versus Schoenoplectus americanus (Noyce and Megonigal 2021); however, such differences are not always observed (Emery and Fulweiler 2014). Plant species composition affects $\mathrm{CH}_{4}$ emissions through several mechanisms (Koebsch et al. 2013; Moor et al. 2017; Mueller et al. 2020). The availability of electron donors is largely determined by primary productivity which varies with species composition (Megonigal et al. 2004). Species composition also regulates electron acceptor availability through rhizosphere processes such as root oxygen loss (Calhoun and King, 1997; Jespersen et al. 1998; Colmer 2003) and rhizosphere regeneration of ferric iron (Neubauer et al, 2005; Sutton-Grier and Megonigal, 2011). Methane can be transported to the atmosphere via aerenchyma tissue, bypassing the emission barriers caused by slow $\mathrm{CH}_{4}$ diffusion rates through soils and soil-surface $\mathrm{CH}_{4}$ oxidation zones (Le Mer and Roger 2001; Ding et al. 2005; Sorrell et al. 2013; Villa et al. 2020). This is important because $\mathrm{CH}_{4}$ oxidation can consume $70 \%$ or more of the $\mathrm{CH}_{4}$ produced in tidal wetland soils (Megonigal and Schlesinger 2002).

In tidal marshes, water table position and periods of soil inundation are controlled by hydrologic factors such as tides, soil hydraulic conductivity, distance from open water, and soil surface elevation relative to sea surface elevation. Elevation zonation subdivides tidal marshes into low marsh areas that are frequently inundated by the tides, and high marsh areas that are 
infrequently influenced by the tides. Water table depth influences soil oxygen availability (Epp and Chanton 1993; Gilbert and Frenzel 1995), and hence the potential for aerobic processes such as $\mathrm{CH}_{4}$ oxidation (Grünfield and Brix 1999; Megonigal and Schlesinger 2002). Soils in low marsh areas that are permanently or frequently inundated experience low rates of $\mathrm{O}_{2}$ diffusion and sustain anaerobic environments where methanogenesis can occur (Ding et al. 2010). Tidal wetland studies have documented correlations between elevation, water level, and $\mathrm{CH}_{4}$ emissions (Grünfield and Brix 1999; Altor and Mitsch 2006; Ding et al., 2010; Audet et al. 2013), implicating hydroperiod as a dominant influence on wetland $\mathrm{CH}_{4}$ emissions.

Both plant community composition and water table depth have proven to be effective proxies for predicting $\mathrm{CH}_{4}$ emissions in non-tidal wetland ecosystems such as peatlands (Bubier et al. 1995; Couwenberg et al. 2011; Dias et al. 2010; Audet et al. 2013). Wetland plant species exhibit different tolerances to inundation (Sorrell et al. 2000; Vann and Megonigal 2003), leading to varying plant community composition across elevation gradients (Perry and Hershner 1999). Wetland vegetation is well suited for serving as a proxy to predict $\mathrm{CH}_{4}$ fluxes due to direct and indirect influences of plant species on labile soil organic carbon (i.e. root exudates), soil moisture, and $\mathrm{CH}_{4}$ gas transport via plant aerenchyma tissue (Couwenberg et al. 2011). Previous studies have established direct links between plant species composition and $\mathrm{CH}_{4}$ fluxes (Shäefer et al. 2011; Audet et al. 2013; Bhullar et al. 2014). Plant species composition has been established and implemented as a means to accurately predict $\mathrm{CH}_{4}$ fluxes from peatlands (Couwenberg et al. 2011; Dias et al. 2010), but this development has not yet occurred for tidal wetland systems. Water table depth, as influenced by relative elevation, has also proven to be a good proxy for predicting $\mathrm{CH}_{4}$ emissions in peatlands as water table level determines aerobic/anaerobic zones and redox states in the soil profile (Ding et al. 2010). Plant community composition, water table depth, and elevation co-vary in wetlands such that these parameters are often used as proxies for one another (Broome et al. 1995; Tuxen et al. 2011; Holmquist et al. 2021).

The objective of this study was to assess and advance our understanding of the potential of hydrology and plant species composition as proxies for $\mathrm{CH}_{4}$ emissions in brackish marshes at the site scale. We hypothesized that $\mathrm{CH}_{4}$ emissions would vary across strata defined by plant community composition and elevation in a tidal marsh that was relatively homogenous with respect to salinity. If such variation exists it suggests that a deeper process-level understanding of the biogeochemical consequences of plant-microbehydrology interactions can be widely applied to develop improved proxies to predict $\mathrm{CH}_{4}$ emissions in tidal wetlands. We measured $\mathrm{CH}_{4}$ fluxes in two brackish marshes on the Deal Island Peninsula on the Eastern Shore of Maryland, USA across four different strata defined by water level and plant community composition. We collected field data on elevation, water level, soil temperature, and soil pore water $\mathrm{SO}_{4}{ }^{2-}$, sulfides, $\mathrm{pH}$, and salinity and laboratory soil incubations using field-collected soil cores to assess potential $\mathrm{CH}_{4}$ production.

\section{Methods}

Study area

Our study area was located on the Deal Island Peninsula in Somerset County, Maryland, USA (38.185172 N, $75.906279 \mathrm{~W})$ (Fig. 1). It consisted of two brackish tidal marshes, one unditched (Unditched) and one that had been ditched then restored (Ditched) located in the same marsh complex. Ditch plugs were installed at the Ditched site in April of 2014 by inserting a plastic polyethylene sheet vertically across the ditch approximately $50 \mathrm{~m}$ upstream from the tidal source and securing the plug using sediment sourced from the ditch upstream of the plug. The Ditched site had an overall lower elevation than the unditched site, and was primarily composed of Juncus roemerianus (black needlerush). The Unditched site had a more diverse species community including $J$. roemerianus, Spartina patens (salt marsh hay), Spartina alterniflora (smooth cordgrass), Phragmites australis (common reed), and Iva frutescens (marsh elder). Plant productivity in tidal marshes in this region includes a period of senescence during the late fall through the early spring, with peak plant productivity occurring in late July through August. Soils on site consist of thick moderately to highly decomposed organic horizons overlying loamy mineral horizons; within Soil Taxonomy they classify as the Mispillion 


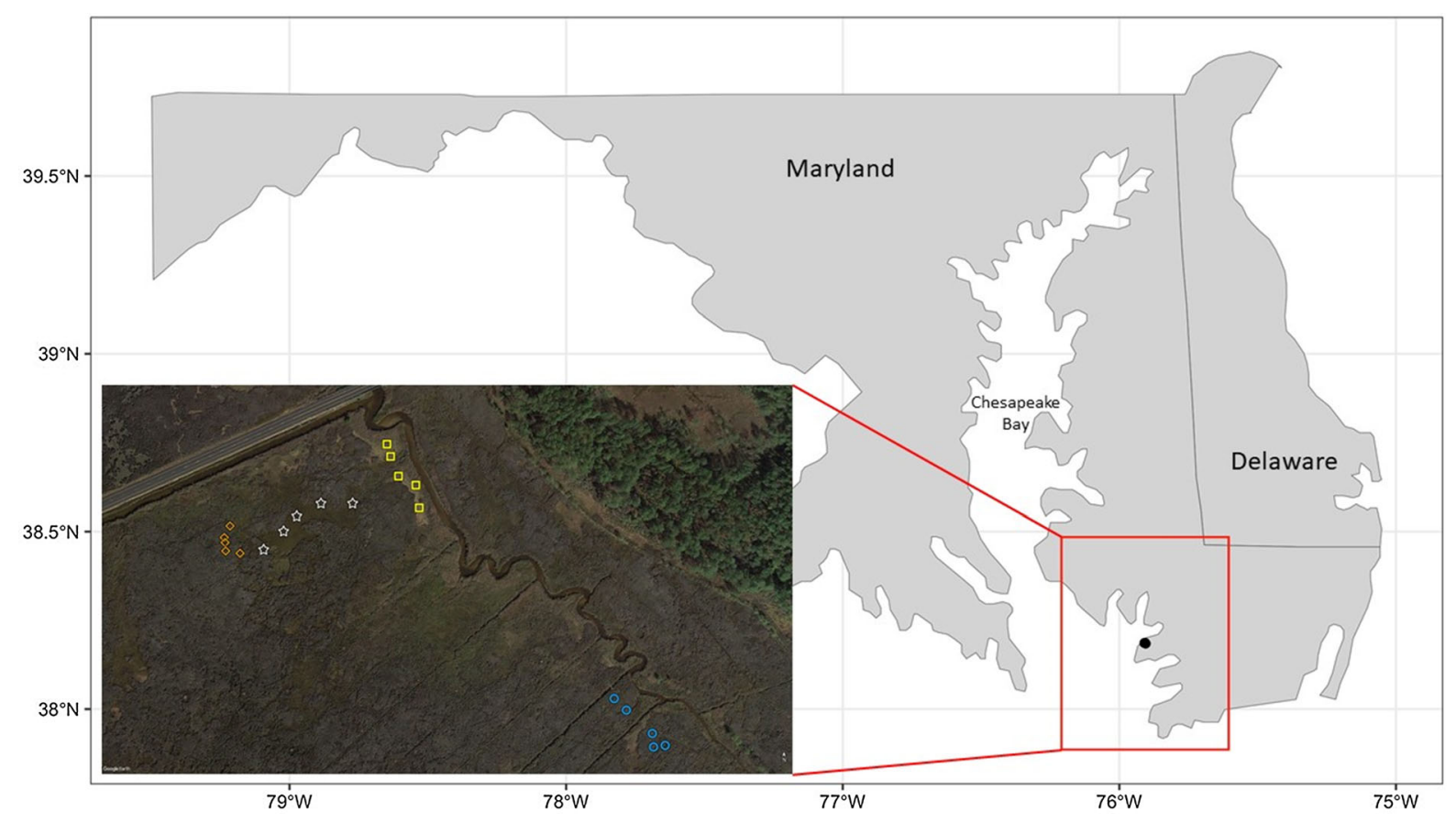

Fig. 1 Study site and plot locations (inset) located on the Eastern Shore of Maryland, USA. S. alterniflora plots are marked with star icons, S. patens plots are marked with squares,

series, Loamy, mixed, euic, mesic, Terric Sulfihemists, which are common estuarine marsh soils in this area. This microtidal marsh had a diurnal tidal range of approximately $0.6 \mathrm{~m}$ as measured in the adjacent tidal creek.

\section{Design}

Four strata that differed in their plant community composition and elevation, both of which are closely associated with water levels, were identified prior to the study from onsite observations and overhead aerial imagery. The strata corresponded to geographic units that may be used to estimate $\mathrm{CH}_{4}$ emissions when engaged in site-specific carbon crediting accounting methodologies (Emmer et al. 2015a, b). Water level variability was primarily controlled by elevation in these marshes, with lower elevations having higher water levels. Two of the strata had a plant community composition dominated by J. roemerianus, but differed in elevation; with one site at a "High" elevation and the other at a "Low" elevation. The High $J$. roemerianus stratum was located at the unditched site and had a mean elevation of $0.334 \mathrm{~m}$ relative to
High-elevation J. roemerianus plots are marked with diamonds, and Low-Elevation J. roemerianus plots are marked with circles

NAVD88, while the Low J. roemerianus stratum was located at the ditched site with a mean elevation $0.305 \mathrm{~m}$. The two additional strata consisted of one dominated by $S$. alterniflora at a relatively low mean elevation of $0.299 \mathrm{~m}$, and one dominated by $S$. patens at a relatively high mean elevation of $0.409 \mathrm{~m}$. Both the Low S. alterniflora and High S. patens strata were located at the Unditched site. One representative area was selected within each stratum that included a range of elevation and plant diversity. A transect of five plots were established in each of the four strata for a total of 20 plots. Plots within a stratum were equally spaced across an area that we considered to be relatively homogenous with respect to plant community composition based on a visual assessment. Note that the objective of our study was to assess drivers of methane emissions rather than estimating emissions from the marsh complex, which would have required a larger number of randomly distributed sites across the full marsh area. Three of the strata were located within 25-50 m of a tidal creek, while one (S. alterniflora) was located in a more central location in the marsh complex approximately $100 \mathrm{~m}$ from a tidal creek. The 20 plots occupied an approximate area of $0.06 \mathrm{~km}^{2}$, 
with each 5-plot strata encompassing an approximate area of $1000 \mathrm{~m}^{2}$.

Field methods

We sampled monthly from April to December 2015; samples were not taken from January to March under the assumption that $\mathrm{CH}_{4}$ production would be negligible due to low temperatures (Marsh et al. 2005). Methane flux, air temperature, pore water $\mathrm{pH}$, and pore water concentrations of $\mathrm{SO}_{4}{ }^{2-}$, hydrogen sulfide, and $\mathrm{CH}_{4}$ were measured at each plot. Soil temperature at $10 \mathrm{~cm}$ was recorded at two plots per stratum hourly during the sampling season using HOBO $8 \mathrm{k}$ Pendant sensors (Onset Corp., Bourne, MA). Soil temperature and water level data were not collected during the month of April because loggers were not ready for deployment until May.

Each of the 20 sample plots received a customfabricated square aluminum metal collar that was permanently inserted into the marsh to a depth of $10 \mathrm{~cm}$ nine months prior to the first sample. Flux chambers were constructed of an aluminum frame made of $2.5-\mathrm{cm}$ wide angle stock covered with transparent polycarbonate plastic film. Chambers were placed on top of the collar about 10 min prior to sampling. Chambers were equipped with a closed-cell neoprene strip on the top and bottom, which when clamped to the collar assured an airtight seal (Yu et al. 2013). The taller plants in the J. roemerianus strata were accommodated without damaging plant stems by stacking chambers. Opaque chamber lids with a sampling port were clamped to the top of the chamber to complete the seal. Chambers had a height of $69.5 \mathrm{~cm}$ and an interior length and width of $49.5 \mathrm{~cm}$, yielding a total volume of $0.17 \mathrm{~m}^{3}$ for single chambers and $0.34 \mathrm{~m}^{3}$ for double chambers. In order to prevent the weight of the observer from causing ebullition due to soil compression (Sorrell et al. 2013), each plot had a $3 \mathrm{~m}$ wooden boardwalk suspended above the soil surface by PVC legs for approaching the flux collar.

Methane flux samples were collected over a 1-h period from the 5 replicate flux plots in a given stratum. An initial sample was taken immediately after each chamber was sealed with four subsequent samples taken at approximately 15-min intervals for a total of 25 samples ( 5 per plot) over the 1-h period. Using a $30 \mathrm{~mL}$ syringe, the sampling port was opened and then expelled back into the chamber three to five times before each sample was taken. Each $18 \mathrm{~mL}$ air sample was withdrawn from the chamber and injected into a $\mathrm{N}_{2}$-flushed 12-mL Exetainer vial with rubber septum until analysis (Yu et al. 2013). Air temperature within the sampling chamber was recorded upon the collection of each flux sample from thermometers affixed to the interior of each chamber.

Porewater samples were taken at $10 \mathrm{~cm}$ depth using a porewater sipper and syringe (Fisher et al. 2013) and analyzed for pore water $\mathrm{CH}_{4}$, hydrogen sulfide (unfiltered), $\mathrm{pH}$ (unfiltered), salinity (unfiltered), and $\mathrm{SO}_{4}{ }^{2-}$ (filtered through a $0.45-\mu \mathrm{m}$ filter) as described by Keller et al. (2009). Porewater $\mathrm{CH}_{4}$ was collected by withdrawing $15 \mathrm{~mL}$ of pore water, after which $15 \mathrm{~mL}$ of ambient air was drawn into the syringe and the syringe capped. The sample was then agitated for 1-2 min for the $\mathrm{CH}_{4}$ to be stripped into the drawn air, the stripped water was expelled, and the gas sample was stored in $\mathrm{N}_{2}$-flushed Exetainers for analysis (Keller et al. 2009). Hydrogen sulfide samples were diluted in a 1:1 ratio of sample to sulfide antioxidant buffer in the field to prevent sulfide volatilization and oxidation (Koch et al. 1990). Hydrogen sulfide and $\mathrm{pH}$ samples were analyzed the same day as sample collection; salinity was analyzed within two weeks in the laboratory using a YSI Model 3100 conductivity meter; and all other pore water samples were frozen and analyzed during the winter of 2016. We chose a sampling depth of $10 \mathrm{~cm}$ because it is within the root zone of the emergent species within the strata and close enough to the surface to be influenced by both aerobic and anaerobic processes in response to the fluctuating water table.

Additional data were collected during the July 2015 sampling event, which was predicted to be during a peak $\mathrm{CH}_{4}$ emission period. We collected porewater at $20 \mathrm{~cm}$ depth in addition to $10 \mathrm{~cm}$ and analyzed it for the same analytes excluding $\mathrm{CH}_{4}$ but including ferrous iron $\left(\mathrm{Fe}^{2+}\right)$. We measured at $20 \mathrm{~cm}$ during this period of predicted high emissions to understand processes at a depth that is more dominated by anaerobic conditions.

Water level was measured at each stratum in order to determine water levels at the time of sampling and antecedent water level conditions during the two-week period leading up to the sampling period. Water level recorders (HOBO U20-L, Onset Corp, Bourne, MA) were installed adjacent to the chamber transects to continuously record water levels in the marsh; one was 
also installed in the tidal creek adjacent to the field site during the field season. We deployed two water level loggers in each stratum, except for the low water table J. roemerianus stratum, which had one water level logger due to its small area relative to the other strata. Barometric pressure was collected onsite to correct the unvented loggers (HOBO U20-L, Onset Corp, Bourne, MA). We surveyed the elevation of all 20 plots and water level logger locations using a Realtime Networking Global Positioning System (RTN GPS) unit, which provides elevation data with approximately $2 \mathrm{~cm}$ accuracy (http://www.keynetgps.com).

Soil cores were collected during the July sampling event and analyzed for potential anaerobic $\mathrm{CH}_{4}$ and $\mathrm{CO}_{2}$ production. Cores were collected from approximately $0-40 \mathrm{~cm}$ depth using a circular metal gouge corer with a diameter of $5.1 \mathrm{~cm}$. The corer was inserted into the marsh, with careful attention paid to minimize compaction of the soft peat. The core was removed and cut at a depth of $20 \mathrm{~cm}$, yielding two depth increments per plot. Cores were placed into sample bags in which as much air as possible was removed. The cores were then placed in a cooler with ice and transported back to the laboratory, where each bag was flushed three times with nitrogen gas to remove oxygen, stored on ice during transport, and placed in a $4{ }^{\circ} \mathrm{C}$ cold room until processing. Water for these incubations was collected from the bore hole from which the core was removed, stored on ice for transport back to the lab, purged with nitrogen gas to remove oxygen before being sealed and placed in a cold room at $4{ }^{\circ} \mathrm{C}$. Soil cores and water samples were stored in the cold room within $8 \mathrm{~h}$ of their collection and incubated within 5 days.

\section{Laboratory analyses}

Flux chamber headspace samples were measured on a Varian 450 gas chromatograph using a Combi-Pal autosampler and corrected for dilution of $18 \mathrm{~mL}$ of sample into $12 \mathrm{~mL}$ of $\mathrm{N}_{2}$ in the Exetainer. Flux rate was calculated as the linear increase in headspace $\left[\mathrm{CH}_{4}\right]$ over time based on measurements of chamber temperature and volume and assuming atmospheric pressure $(\mathrm{n}=147$ fluxes). The linear slope was calculated in Excel using the Regression function. Data points were excluded from the regression if they indicated an ebullition event (large spike in $\left[\mathrm{CH}_{4}\right]$ ) or an Exetainer leak (large drop in $\left[\mathrm{CH}_{4}\right]$ ). Fluxes were calculated from five points $(\mathrm{n}=79)$, four points $(n=61)$, but never from fewer than three points $(n=23)$. No flux measurements were excluded based on arbitrary regression $\mathrm{R}^{2}$ or $\mathrm{p}$ value limits to prevent introducing bias against low fluxes that approach the detection limits of our experimental system (Pitz and Megonigal 2017). However, fluxes were excluded in several cases where an ebullition event or leak was large compared to the $\mathrm{CH}_{4}$ flux rate $(\mathrm{n}=17)$. In cases where there was no significant trend in headspace $\left[\mathrm{CH}_{4}\right]$ and no evidence of ebullition or leaks the flux was assigned a value of zero $(n=16)$. Because most of the excluded fluxes were collected during periods of low $\mathrm{CH}_{4}$ flux, they had relatively little influence on the annual flux calculation.

To estimate annual emissions we averaged rates from each measurement campaign. We assumed that the fluxes in the unsampled months of January, February, and March were equal to our observed values from April. The twelve monthly values were averaged and converted to annual units. While this method likely overestimated $\mathrm{CH}_{4}$ emissions, overestimation is the conservative and therefore preferable approach for carbon credit accounting (Needelman et al. 2018).

Hydrogen sulfide was determined with a Lazar Laboratory model $146 \mathrm{~S}$ sulfide electrode. Sulfide antioxidant buffer was prepared the day before sample collection with deoxygenated $\left(\mathrm{N}_{2}\right.$-stripped) distilled water, sodium salicylate, sodium hydroxide, and ascorbic acid according to Koch et al. (1990). A standard curve created from a serial dilution of a $\mathrm{Na}_{2} \mathrm{~S} /$ buffer solution prepared on the day of each sampling event and readings were complete within $4 \mathrm{~h}$ of sample collection. The $\mathrm{pH}$ was measured with a YSI Pro Plus (https://www.ysi.com) $\mathrm{pH}$ meter calibrated with standards at pH 7.0 and 10.0. Salinity was measured with a calibrated conductivity/salinity electrode. The remaining analytes $\mathrm{SO}_{4}{ }^{2-}$ and $\mathrm{Fe}^{2+}$ were quantified at the Chesapeake Biological Laboratory, Solomons Island, MD. Reduced iron was analyzed according to EPA method 200.1 and $\mathrm{SO}_{4}{ }^{2-}$ was analyzed according to the National Environmental Methods Index Standard Methods: 4110B for ions in water by ion chromatography (www.nemi.gov).

Sulfate depletion was calculated by assuming the $\mathrm{SO}_{4}{ }^{2-}$ concentration in the absence of sulfate reduction was that of full-strength marine seawater (Canfield 2004) diluted to the observed salinity of our 
porewater sample. We then divided our observed $\mathrm{SO}_{4}{ }^{2-}$ concentration by this expected concentration of $\mathrm{SO}_{4}{ }^{2-}$ to estimate the consumption of $\mathrm{SO}_{4}{ }^{2-}$ (i.e. relative depletion) in the porewater.

Soil cores collected for incubations were removed from cold storage within 5 days of collection and placed into an anaerobic hood containing a $\mathrm{N}_{2} / \mathrm{H}_{2}$ mixture (Megonigal and Schlesinger 2002). Two sections were removed from each core, yielding a 8-12 cm depth sample and a $28-32 \mathrm{~cm}$ depth sample. The outer $10 \mathrm{~mm}$ (approximately) of the resulting disks were removed to expose the center of the core, which was assumed to have had minimal $\mathrm{O}_{2}$ exposure from collection to processing. We then removed as many live roots as feasible. Five grams of wet soil material was placed in a $35-\mathrm{mL}$ serum bottle with $5 \mathrm{~mL}$ of the degassed water from the core hole. Headspace samples of $0.5 \mathrm{~mL}$ were taken daily for approximately two weeks, and were injected directly into a Shimadzu gas chromatograph with a flame ionization detector for $\mathrm{CH}_{4}$ or a LI-COR LI-7000 (LiCor, Lincoln, NE) for $\mathrm{CO}_{2}$. Methanogenesis generally slowed dramatically after 5 days, so our calculations of potential anaerobic $\mathrm{CH}_{4}$ production rates are based on incubation days $1-5$.

\section{Statistical analysis}

Data were analyzed using SAS 9.3 (SAS Institute Inc. Cary, NC). Regression analyses were performed on flux data using Proc Reg to determine the slope of $\mathrm{CH}_{4}$ or $\mathrm{CO}_{2}$ concentration change over time. All variables were evaluated for normality using PROC UNIVARIATE and those that required transformation were log transformed to improve normality. Parameters transformed were: $\mathrm{CH}_{4}$ flux, pore water hydrogen sulfide concentration, pore water $\mathrm{SO}_{4}{ }^{2-}$ concentration, and pore water $\mathrm{CH}_{4}$ concentrations. All parameters were analyzed using PROC MIXED with strata and month in the model statement with repeated measures. Posthoc Tukey mean comparisons were used with $\alpha=0.05$ used to indicate significance.

\section{Results}

Antecedent water levels

Water level data collected during the 2 weeks prior to and during sampling events varied significantly between strata $(\mathrm{p}<0.0001)$ and month $(\mathrm{p}<0.0001)$. Water levels of the $S$. patens stratum were significantly lower than all other strata, with a mean of $9 \mathrm{~cm}$ below the soil surface, while the other strata had similar mean water levels of approximately $1 \mathrm{~cm}$ below the soil surface (Table 1 ). We were unable to test for a strata by month interactive effect because only two wells were deployed in each strata (and only one in the High $J$. roemerianus stratum); however, $S$. patens had a lower mean water level in all months (Derby 2016). Mean water levels were highest in July, August, and October and lowest in May, June, September, and December.

Methane emissions and porewater chemistry by strata

Average $\mathrm{CH}_{4}$ flux over the study varied significantly between strata $(\mathrm{p}<0.0001)$ and month $(\mathrm{p}<0.0001)$, and had a significant interactive effect $(\mathrm{p}=0.018)$. Methane emissions from the four strata ranked $S$. alterniflora $\gg$ High J. roemerianus $>$ Low J. roemerianus $=S$. patens $($ Table 1$)$. Mean $\mathrm{CH}_{4}$ emissions from the $S$. alterniflora stratum was 2.72 times greater than the next highest $\mathrm{CH}_{4}$ emitter (Table 1) despite similar inundation regimes among the three highest emitting strata. High $\mathrm{CH}_{4}$ emissions in the S. alterniflora stratum coincided with significantly higher porewater $\mathrm{CH}_{4}$ concentrations and lower $\mathrm{SO}_{4}{ }^{2-}$ concentrations than the other three strata (Table 1). Porewater salinity in the $S$. alterniflora stratum was similar to other strata (Table 1) suggesting that relatively low $\mathrm{SO}_{4}{ }^{2-}$ concentrations were due to high rates of $\mathrm{SO}_{4}{ }^{2-}$ consumption. Indeed, $\mathrm{SO}_{4}{ }^{2-}$ was depleted by $61 \%$ in the $S$. alterniflora stratum. Sulfate depletion was significantly different between strata $(\mathrm{p}<0.0001)$ and month $(\mathrm{p}<0.0001)$ and ranked $S$. alterniflora $=$ High $J$. roemerianus $>$ Low $J$. roemerianus $>S$. patens. Sulfate depletion rates in the $S$. alterniflora stratum were over two times greater than those seen in low J. roemerianus (Table 1). Low $\mathrm{SO}_{4}{ }^{2-}$ concentrations in the $S$. alterniflora stratum were accompanied by significantly higher amounts of 
hydrogen sulfide $\left(72 \mathrm{mg} \mathrm{L}^{-1}\right)$ as compared to the other three strata (all $<20 \mathrm{mg} \mathrm{L}^{-1}$ ).

The $S$. patens stratum had the lowest mean porewater $\mathrm{CH}_{4}$ concentrations and $\mathrm{SO}_{4}{ }^{2-}$ depletion rates, with only $1.4 \% \mathrm{SO}_{4}{ }^{2-}$ depleted. S. patens also exhibited the highest mean concentrations of reduced iron (i.e. ferrous iron, $\mathrm{Fe}^{2+}$ ) during the single campaign when it was measured, with $72 \mathrm{mg} \mathrm{L}^{-1}$ of ferrous iron in porewater collected $10 \mathrm{~cm}$ below the soil surface (Table 1). None of the other three strata had reduced iron porewater concentrations exceeding $0.8 \mathrm{mg} \mathrm{L}^{-1}$. S. patens also had a significantly lower mean porewater salinity (12.3 ppt) than the other three strata, which ranged in mean salinity from 14.2 to 14.8 ppt. The High and Low J. roemerianus and $S$. alterniflora strata were not significantly different in porewater iron concentrations or salinity (Table 1).

The difference in elevation between the two $J$. roemerianus strata was not highly apparent in the water level and $\mathrm{CH}_{4}$-related attributes we measured. The two strata were not significantly different from one another in salinity, $\mathrm{SO}_{4}{ }^{2-}$ concentrations, sulfide concentrations, percent $\mathrm{SO}_{4}{ }^{2-}$ depleted, porewater $\mathrm{CH}_{4}$ concentrations, and reduced iron concentrations (Table 1).

The highest $\mathrm{CH}_{4}$ emissions were observed in July, August, and September; the lowest were observed in April, November, and December (Fig. 2). Significant strata by month interactions were observed in May, June, and September. In May and June, S. alterniflora was not significantly different from any strata other than Low J. roemerianus; all other strata were not significantly different from one another. In September, S. alterniflora was not significantly different from any strata other than S. patens; all other strata were not different from one another. No significant withinmonth differences were observed in April, July, August, October, November and December (Derby 2016). Porewater $\mathrm{CH}_{4}$ exhibited a similar seasonal trend as $\mathrm{CH}_{4}$ emissions, with the highest concentrations in the months July through November (Derby 2016).

Anaerobic incubations

Surficial soils $(8-12 \mathrm{~cm})$ from the $S$. patens stratum had the lowest $\mathrm{CH}_{4}$ production, highest $\mathrm{CO}_{2}$ production and a significantly higher ratio of $\mathrm{CO}_{2}: \mathrm{CH}_{4}$ production $($ ratio $=993$ ) that the other strata. At the 


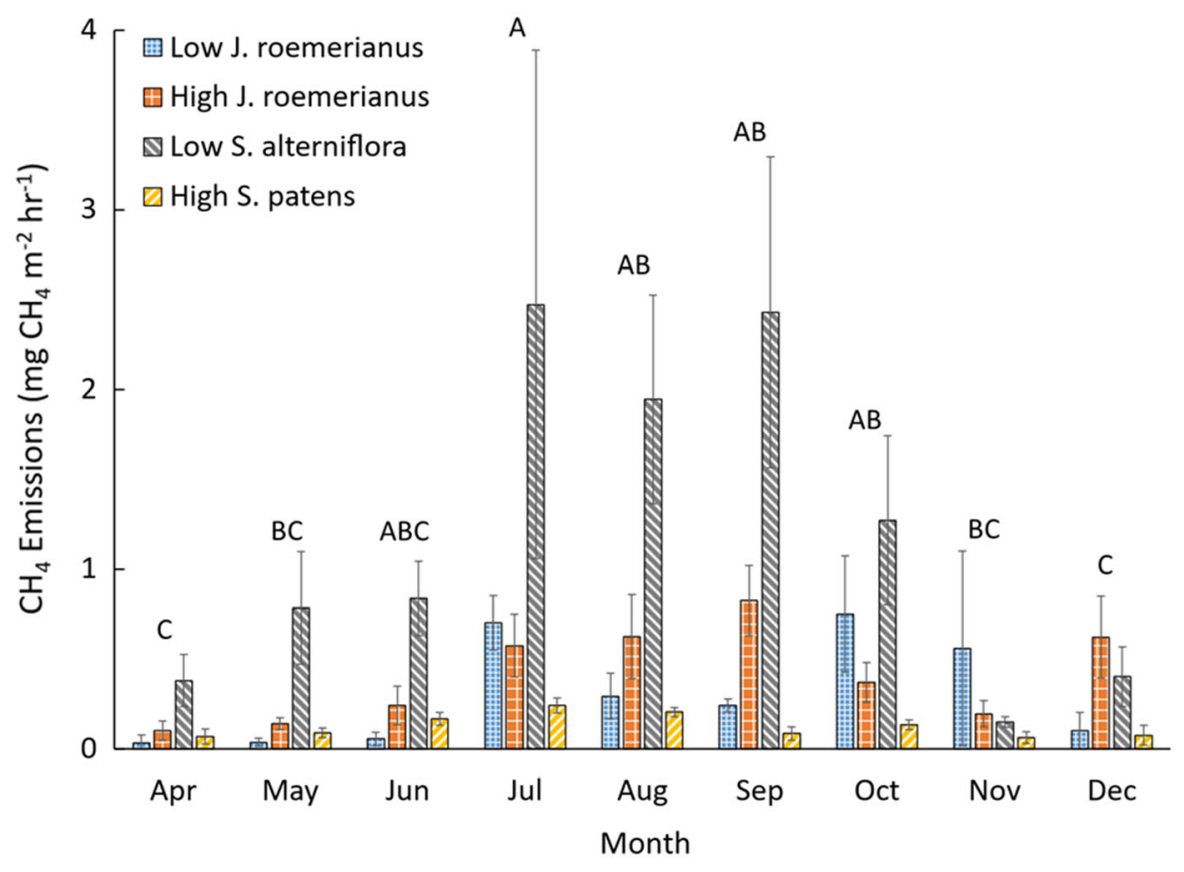

Fig. 2 Mean hourly methane flux during the sampling period in standard error; significant differences are shown with letters. ANOVA results of the log transformed data showed significant differences between strata $(p<0.0001)$, month $(p<0.0001)$ and strata*month $(\mathrm{p}=0.0182)$ Maryland's Eastern Shore. "Low" vs "High" refers to comparative elevations within the site. Error bars signify

Table 2 Mean values of $\mathrm{Mol} \mathrm{CO}_{2}$ and $\mathrm{CH}_{4}$ produced on day five of anaerobic soil incubations and the ratio of $\mathrm{CO}_{2}$ to $\mathrm{CH}_{4}$ produced from soils collected from a brackish marsh complex

\begin{tabular}{lccc}
\hline Strata & $\begin{array}{l}\text { Mol of } \mathrm{CH}_{4} \text { produced at } 10 \mathrm{~cm} \text { in } \\
\text { anaerobic incubations }\end{array}$ & $\begin{array}{l}\text { Mol of } \mathrm{CO}_{2} \text { Produced at } 10 \mathrm{~cm} \text { in } \\
\text { anaerobic incubations }\end{array}$ & $\begin{array}{l}\text { Ratio of } \mathrm{CO}_{2}: \mathrm{CH}_{4} \text { produced at } 10 \mathrm{~cm} \\
\text { in anaerobic incubations }\end{array}$ \\
\hline $\begin{array}{l}\text { S. alterniflora } \\
\text { S. patens }\end{array}$ & $13.8^{\mathbf{A}} \pm 5.8$ & $101.5^{\mathrm{A}} \pm 19.0$ & $39.8^{\mathrm{A}} \pm 22.1$ \\
$\begin{array}{l}\text { J. roemerianus } \\
\text { (Low elevation) }\end{array}$ & $0.4^{\mathbf{B}} \pm 0.1$ & $229.5^{\mathrm{B}} \pm 16.6$ & $933.1^{\mathrm{B}} \pm 324.2$ \\
$\begin{array}{c}\text { J. roemerianus } \\
\text { (high elevation) }\end{array}$ & $0.9^{\mathbf{B}} \pm 0.1$ & $171.8^{\mathrm{AB}} \pm 29.7$ & $199.1^{\mathrm{A}} \pm 31.1$ \\
\hline
\end{tabular}

Superscript letters denote statistical differences between strata. Means with the different letters have statistically significant differences. Standard error is presented with each mean

other extreme was the $S$. alterniflora stratum which produced substantially more $\mathrm{CH}_{4}$ and less $\mathrm{CO}_{2}$ than the other strata, and therefore had the lowest $\mathrm{CO}_{2}: \mathrm{CH}_{4}$ ratio (ratio $=40$ ) among the four sites (Table 2). The two J. romerianus strata fell in between these extremes with a $\mathrm{CO}_{2}: \mathrm{CH}_{4}$ ratio of about 200 (Table 2), though there were no significant differences in $\mathrm{CO}_{2}: \mathrm{CH}_{4}$ ratio between these strata and $S$. alterniflora. The $10 \mathrm{~cm}$ incubations produced significantly more $\mathrm{CH}_{4}$ and $\mathrm{CO}_{2}$ than those from $30 \mathrm{~cm}$ depth $(\mathrm{p}=0.04$, data not shown, Derby 2016).

\section{Discussion}

Methane emissions varied by plant community type and hydrologic setting, suggesting that these variables have potential to be developed into cost-effective 
proxies to estimate $\mathrm{CH}_{4}$ emissions from tidal marshes. Mean emissions across strata ranked as S. alterniflora $>$ High-elevation J. roemerianus $>$ Low-elevation $J$. roemerianus $>S$. patens (Table 1). The mechanisms that led to these differences among strata need to be understood to develop vegetation- and hydrology-based proxies, as their application is likely to be more complex than the salinity proxity.

We attribute the low emissions from the $S$. patens stratum to a combination of relatively low water levels, shallow rooting depth, and higher mineral inputs, all of which have the capacity to suppress $\mathrm{CH}_{4}$ production and promote $\mathrm{CH}_{4}$ oxidation. It is well established that $\mathrm{CH}_{4}$ production is suppressed by alternative electron acceptors such as $\mathrm{O}_{2}, \mathrm{Fe}(\mathrm{III})$ and $\mathrm{SO}_{4}{ }^{2-}$ (Roden and Wetzel 2003; Neubauer et al. 2005; Poffenbarger et al 2011; Holm et al. 2016). Relatively high $\mathrm{O}_{2}$ flux into the upper soil surface $(0-10 \mathrm{~cm}$ depth) would be favored by both the relatively thick aerobic zone (i.e. deeper water-table) and shallow distribution of root biomass that is characteristic of $S$. patens communities (Bernal et al. 2016). Mean antecedent water depth was $9 \mathrm{~cm}$ deep in this stratum compared to other strata with water levels near the soil surface.

Because the majority of $S$. patens roots are in the top $10 \mathrm{~cm}$ of the soil profile (Windham 2001), it is likely that root oxygen loss was also an $\mathrm{O}_{2}$ source in this community. $\mathrm{O}_{2}$ suppresses methanogenesis via electron donor competition by two mechanisms, directly as an electron acceptor for aerobic bacteria and indirectly by regenerating poorly crystalline iron oxides on the root surface (i.e. iron plaque). Rootdeposited iron plaque is rapidly consumed by ironreducing bacteria (Weiss et al. 2003, 2004), suppressing both $\mathrm{SO}_{4}{ }^{2-}$ reduction and methanogenesis (Neubauer et al. 2005). This mechanism is consistent with our observation that the $S$. patens community had dramatically higher concentrations of reduced iron (measured only in July) and $\mathrm{SO}_{4}{ }^{2-}$ than the other strata, and the least $\mathrm{SO}_{4}{ }^{2-}$ depletion (Table 1). The close proximity of this site to the tidal creek may have also allowed for greater mineral inputs during flooding events to support iron cycling. Finally, if rates of methanotrophy are $\mathrm{O}_{2}$-limited as studies suggest (King 1996; Lombardi et al. 1997; Megonigal and Schlesinger 2002), then relatively high rates of $\mathrm{CH}_{4}$ oxidation would be expected to further decrease the amount of $\mathrm{CH}_{4}$ emitted through passive diffusion through plants, as documented in other tidal wetlands (Megonigal and Schlesinger 2002).

The $S$. alterniflora stratum had the highest average $\mathrm{CH}_{4}$ emissions and porewater chemistry that differed from the $S$. patens community in several respects (Table 1). The $S$. alterniflora stratum was in the center of the marsh complex (Fig. 1). Because hydrologic fluxes generally decrease with increasing distance from the tidal creek (Jordan et al. 1985), it is likely that soils in the $S$. alterniflora stratum had relatively slow rates of advection compared to the other strata. Indeed, water table depths decreased relatively slowly after floods in the $S$. alterniflora stratum (Derby 2016). This hydrologic difference likely decreased rates of advective transport of $\mathrm{O}_{2}$ and $\mathrm{SO}_{4}{ }^{2-}$ to the soil profile to replenish these electron acceptors. We propose that the relatively low inputs of $\mathrm{SO}_{4}{ }^{2-}$ to the $\mathrm{S}$. alterniflora stratum led to $\mathrm{SO}_{4}{ }^{2-}$ limitation of $\mathrm{SO}_{4}{ }^{2-}$ reduction rates, allowing methanogens to compete more effectively with sulfate-reducing bacteria for electron donors. Porewater evidence supporting this interpretation includes low concentrations of $\mathrm{Fe}^{2+}$, high $\mathrm{SO}_{4}{ }^{2-}$ depletion, and high concentrations of both hydrogen sulfide and $\mathrm{CH}_{4}$. This interpretation is also consistent with the results of the July anaerobic incubations showing that the $\mathrm{CO}_{2}: \mathrm{CH}_{4}$ ratio was lowest in S. alterniflora soils and highest in S. patens soils. Because aerobic respiration, sulfate reduction, and iron reduction generate $\mathrm{CO}_{2}$ rather than $\mathrm{CH}_{4}$, these data suggest that methanogens had relatively little competition for organic carbon and $\mathrm{H}_{2}$ in the $S$. alterniflora stratum.

Water table depths in the High and Low $J$. roemerianus strata were similar to the $S$. alterniflora stratum but metrics related to $\mathrm{CH}_{4}$ emissions were consistently lower than the $S$. alterniflora and higher than the $S$. patens strata, namely $\mathrm{CH}_{4}$ emissions, porewater $\mathrm{SO}_{4}{ }^{2-}$ concentrations, and anaerobic incubation $\mathrm{CO}_{2}: \mathrm{CH}_{4}$ ratio. The difference in $\mathrm{CH}_{4}$ emissions between $S$. alterniflora and the J. roemerianus strata cannot be explained by water levels, salinity, $\mathrm{pH}$, or reduced iron because they were not significantly different between these strata. For example, mean water table depth in the S. alterniflora stratum and the two J. roemerianus strata were within $1 \mathrm{~cm}$ of each other, while emissions were 2.5 times greater in the $S$. alterniflora stratum. The J. roemerianus strata were closer to the tidal creek and presumably $\mathrm{CH}_{4}$ production was not limited by tidal inputs of 
$\mathrm{SO}_{4}{ }^{2-}$ supply as we suspect was the case in the $S$. alterniflora stratum. However, the relatively low $\mathrm{CH}_{4}$ emissions in the J. roemerianus strata compared to $S$. alterniflora may also have been related to plant traits that regulate $\mathrm{CH}_{4}$ emissions by influencing the balance between $\mathrm{CH}_{4}$ production and oxidation (Sutton-Grier and Megonigal 2011; Mueller et al. 2020), which itself is influenced by traits that affect $\mathrm{CH}_{4}$ transport through plants (Komiya et al. 2020). Mueller et al. (2020) proposed that plant traits vary across species such that some push the balance between these opposing processes toward net $\mathrm{CH}_{4}$ production while others favor net $\mathrm{CH}_{4}$ oxidation. We hypothesize that among the dominant species present at the site, S. alterniflora favors net $\mathrm{CH}_{4}$ production while J. roemerianus favors net $\mathrm{CH}_{4}$ oxidation, and that the lower $\mathrm{CH}_{4}$ emissions rates in the J. roemerianus strata may have been due to relatively high rates of root oxygen loss by $J$. roemerianus. This interpretation is supported in part by data on porewater $\left[\mathrm{SO}_{4}{ }^{2-}\right]$, which mediates the outcome of competition between sulfate-reducing bacteria and methanogens. Porewater $\left[\mathrm{SO}_{4}{ }^{2-}\right]$ was $4.5 \mathrm{mM}$ in the $S$. alterniflora stratum but exceeded $6 \mathrm{mM}$ in the $J$. roemerianus strata where $\mathrm{CH}_{4}$ emissions rates were relatively low. Although this difference in porewater $\left[\mathrm{SO}_{4}{ }^{2-}\right]$ seems small, the relationship between these variables is non-linear and displays a threshold value above which sulfate reduction dominates and below which methanogenesis dominates (Megonigal et al. 2004). There is a general lack of $\mathrm{CH}_{4}$-relevant porewater data for coastal wetlands, but a robust record from a brackish marsh located $100 \mathrm{~km}$ from the study site in Chesapeake Bay observed that porewater $\left[\mathrm{CH}_{4}\right]$ declined abruptly when $\mathrm{SO}_{4}{ }^{2-}$ concentrations exceeded approximately 4 to $6 \mathrm{mM}$ (Keller et al. 2009). We propose that the $S$. alterniflora and J. roemerianus strata fell on opposite sides of this threshold.

Although floodwater salinity can be an effective proxy for porewater $\mathrm{SO}_{4}{ }^{2-}$ concentrations when comparing sites across large spatial scales (Poffenbarger et al. 2011), our data demonstrate the limitations of using the salinity proxy at local scales. Variation among strata in $\mathrm{SO}_{4}{ }^{2-}$ concentration and $\mathrm{SO}_{4}{ }^{2-}$ depletion may have been caused by variation in rates of $\mathrm{SO}_{4}{ }^{2-}$ transport from tidal floodwater into soils, sulfide oxidation related to $\mathrm{O}_{2}$ diffusion from water table depth or root $\mathrm{O}_{2}$ loss, or primary production (i.e. carbon availability). We cannot distinguish among these mechanisms with the present dataset. Sulfate depletion was a better indicator of $\mathrm{CH}_{4}$ flux than salinity or $\mathrm{SO}_{4}{ }^{2-}$ concentration alone and may prove to be a superior proxy for $\mathrm{CH}_{4}$ emissions in tidal brackish marshes (Keller et al. 2009; Noyce and Megonigal 2021).

Within our strata, $\mathrm{CH}_{4}$ production did not strictly follow the conventional interpretation that differences in the free energy yield among competing microbial respiration processes means that just one process dominates microbial respiration at a time, with methanogenesis expected to occur only when all other electron acceptors are fully (or nearly) depleted. Our data suggest that peak sulfate reduction activity was occurring concurrently with peak $\mathrm{CH}_{4}$ production in the $S$. alterniflora stratum which had both the highest mean pore water hydrogen sulfide concentrations and the lowest $\mathrm{SO}_{4}{ }^{2-}$ concentrations. We attribute this to spatial variation in electron donors and acceptors that creates microsites of high $\mathrm{SO}_{4}{ }^{2-}$ depletion and methanogenesis. Microsites have been shown to produce small amounts of $\mathrm{CH}_{4}$ in upland forested systems, originally thought to be too dry and too aerobic to produce this greenhouse gas (Megonigal and Guenther 2008). Microsites also exist in tidal marsh soils due to local (i.e. rhizosphere) consumption of electron acceptors at rates faster than they can be replenished (e.g. Rabenhorst et al. 2010).

\section{Carbon offset implications}

Salinity is a useful proxy for $\mathrm{CH}_{4}$ emissions from tidal marshes with salinity regimes $>18$ ppt because $\mathrm{CH}_{4}$ emissions are low in most systems compared to their soil carbon sequestration rates and variation among marshes is small (Poffenbarger et al. 2011). However, tidal brackish marshes at lower salinities may emit enough $\mathrm{CH}_{4}$ to offset a significant fraction of their radiative cooling and variation in $\mathrm{CH}_{4}$ emissions among marshes within a given salinity regime is large. Such uncertainty is accommodated in carbon offset programs such as the Verified Carbon Standard by requiring the project to estimate $\mathrm{CH}_{4}$ emissions by direct monitoring or by using published data, a model, or a proxy that can be demonstrated to be valid for the project site (Needelman et al. 2018). Stratification by hydrology and vegetation characteristics may provide a more effective proxy than salinity to estimate $\mathrm{CH}_{4}$ emissions. 
Table 3 Field-measured salinity and methane flux mean values from four strata in a tidal marsh complex as compared to predicted flux (based on observed salinity) from Poffenbarger

\begin{tabular}{|c|c|c|c|c|c|c|}
\hline Strata & $\begin{array}{l}\text { Salinity } \\
\text { (ppt) }\end{array}$ & $\begin{array}{l}\text { Methane } \\
\text { flux }(\mathrm{Mg} \mathrm{C} \\
\left.\text { ha }^{-1} \text { year }^{-1}\right)\end{array}$ & $\begin{array}{l}\text { Predicted methane flux } \\
\text { from Poffenbarger et al. } \\
\left(\mathrm{Mg} \mathrm{C} \mathrm{ha}^{-1} \text { year }^{-1}\right)\end{array}$ & $\begin{array}{l}\text { Percent } \\
\text { difference from } \\
\text { Poffenbarger } \\
\text { et al. }\end{array}$ & $\begin{array}{l}\text { Percent of carbon } \\
\text { sequestration } \\
\text { offset (actual) (\%) }\end{array}$ & $\begin{array}{l}\text { Percent of carbon } \\
\text { sequestration offset } \\
\text { (predicted) }(\%)\end{array}$ \\
\hline S. alterniflora & 14.2 & 0.67 & 0.29 & $\begin{array}{l}131.0 \% \\
\text { More than } \\
\text { Predicted }\end{array}$ & 45.9 & 19.9 \\
\hline S. patens & 12.3 & 0.07 & 0.37 & $\begin{array}{l}81.0 \% \\
\text { Less than } \\
\text { Predicted }\end{array}$ & 4.8 & 25.3 \\
\hline $\begin{array}{l}\text { J. roemerianus } \\
\text { (Low } \\
\text { Elevation) }\end{array}$ & 14.8 & 0.16 & 0.27 & $\begin{array}{l}40.7 \% \\
\text { Less than } \\
\text { Predicted }\end{array}$ & 11.0 & 18.5 \\
\hline $\begin{array}{l}\text { J. roemerianus } \\
\text { (High } \\
\text { Elevation) }\end{array}$ & 14.8 & 0.22 & 0.27 & $\begin{array}{l}18.5 \% \\
\text { Less than } \\
\text { Predicted }\end{array}$ & 15.1 & 18.5 \\
\hline
\end{tabular}

et al. 2011, with percent differences of actual and predicted carbon sequestration offsets 
required sample size for a given project is a function of the coefficient of variation. The coefficients of variation in our study at peak methane emissions (July) ranged from 0.4 in the $S$. patens stratum to 1.1 in the $S$. alterniflora stratum. To meet this sample size requirement in the S. alterniflora stratum, 56 sampling plots would be required. Further, these points would need to be randomly distributed throughout the strata, further increasing project cost. Due to the high costs of direct monitoring, alternative methods to estimate methane emissions are required such as proxies and models. Under the Verified Carbon Standard, projects seeking to apply these alternative methods must demonstrate that the method was developed or validated in a comparable system as the project area with similar geomorphic, hydrologic, and biological properties and similar management regimes, unless the project can argue that any differences should not have a substantial effect on methane emissions (Emmer et al. 2020a). For this reason, the development and application of vegetation- and hydrology-based proxies will require a deeper process-level understanding of the geomorphic, hydrologic, biological, and management-related drivers of methane emissions.

\section{Conclusions}

Tidal wetland restoration and conservation projects have the potential to mitigate greenhouse gas emissions to the atmosphere and generate carbon credits, but due to the high cost of direct monitoring, a better understanding of the factors influencing wetland $\mathrm{CH}_{4}$ emissions in brackish and freshwater systems (salinity $<18 \mathrm{ppt}$ ) is required to develop cost-efficient proxies to estimate $\mathrm{CH}_{4}$ at site-specific scales. We found significantly different methane emission rates across four strata defined by hydrology and plant community composition that otherwise had similar salinity regimes. We inferred that they deviated from the rates predicted by a salinity proxy due to processes that regulate the availability of competing terminal electron acceptors such as $\mathrm{O}_{2}, \mathrm{Fe}(\mathrm{III})$, and $\mathrm{SO}_{4}{ }^{2-}$ as mediated by plant traits that regulate $\mathrm{CH}_{4}$ emissions. Low $\mathrm{CH}_{4}$ emission rates in the high-elevation $S$. patens stratum was attributed to relatively high availability of electron acceptors such as $\mathrm{O}_{2}, \mathrm{Fe}(\mathrm{III})$, and $\mathrm{SO}_{4}{ }^{2-}$ through tidal inputs and $\mathrm{O}_{2}$ diffusion across soil and root surfaces. Oxygen is particularly important because it suppresses $\mathrm{CH}_{4}$ emissions by three mechanisms: aerobes competing for electron donor compounds are favored over methanogens; $\mathrm{O}_{2}$ regenerates oxidized forms $\mathrm{Fe}$ and $\mathrm{S}$ that support more competitive forms of anaerobic respiration; and $\mathrm{O}_{2}$ supports $\mathrm{CH}_{4}$ oxidation. By contrast, the S. alterniflora stratum was hydrologically isolated from tidal inputs of $\mathrm{Fe}(\mathrm{III})$ and $\mathrm{SO}_{4}$ and supported relatively little $\mathrm{O}_{2}$ driven regeneration of these compounds due to a high water table. This site was the most depleted in $\mathrm{SO}_{4}{ }^{2-}$ and presumably relatively depleted in $\mathrm{O}_{2}$ and $\mathrm{Fe}(\mathrm{III})$ as well, thereby supporting high rates of methanogenesis. The greater $\mathrm{CH}_{4}$ emissions from the low-elevation S. alterniflora stratum than the low and high elevation J. roemerianus strata could not be explained by water table depth, salinity, $\mathrm{pH}$, and $\left[\mathrm{Fe}^{2+}\right]$, suggesting an important role for plant traits such as root $\mathrm{O}_{2}$ loss regulating $\mathrm{CH}_{4}$ emissions at local scales. The mechanisms driving these patterns were not measured directly but likely involve variations in rates of $\mathrm{SO}_{4}{ }^{2-}$ diffusion from tidal floodwater based on site hydrologic connectivity; rates of sulfate regeneration via sulfide oxidation as influenced by $\mathrm{O}_{2}$ diffusion or root $\mathrm{O}_{2}$ loss; and differing plant primary productivity.

Our results suggest that vegetation and hydrology can be effective proxies to estimate $\mathrm{CH}_{4}$ emissions from tidal marshes. Our study contributes to the literature of field studies testing for differences in emissions between strata differentiated by vegetation and/or hydrology. The development and application of vegetation- and hydrology-based proxies is expected to be more complicated than the salinity proxy, necessitating an improved process-level understanding of the biogeochemical consequences of plantmicrobe-hydrology interactions. We included extensive covariates in our sampling design, thereby elucidating insights into the mechanisms by which these potential proxies drive $\mathrm{CH}_{4}$ emissions, which we hope will spur further development of these proxies and promote research on key associated biogeochemical processes.

Acknowledgements We thank the Chesapeake Bay MD National Estuarine Research Reserve Staff, and MD Department of Natural Resources for site access, support and accommodations for this research. We also thank Z. Bernstein, D. Leason, M. Molina, Z. Spencer, K. Willson, and M. Umanzor for their assistance in field data collection and sample processing. We thank the staff of the SERC Biogeochemistry 
lab for assistance with sample processing and preparation, G. Guntenspergen and USGS Staff for their assistance with porewater chemistry sampling equipment, and G. Seibel of UMD ENST for chamber collar construction.

Funding This work was supported by the USDA National Institute of Food and Agriculture, Hatch project 1013805, the NSF Research Coordination Network Program of the Ecosystems Science Cluster (DEB-1655622), the Smithsonian Institution, and the Garden Club of America.

Data availability (data transparency) All data from this manuscript will be made available through the Coastal Carbon Research Coordination Network (https://doi.org/10.25573/serc. 14227085).

\section{Declarations}

Conflict of interest The author declares that they have no conflict of interest.

Code availability (software application or custom code) Not applicable.

Open Access This article is licensed under a Creative Commons Attribution 4.0 International License, which permits use, sharing, adaptation, distribution and reproduction in any medium or format, as long as you give appropriate credit to the original author(s) and the source, provide a link to the Creative Commons licence, and indicate if changes were made. The images or other third party material in this article are included in the article's Creative Commons licence, unless indicated otherwise in a credit line to the material. If material is not included in the article's Creative Commons licence and your intended use is not permitted by statutory regulation or exceeds the permitted use, you will need to obtain permission directly from the copyright holder. To view a copy of this licence, visit http://creativecommons.org/licenses/by/4.0/.

\section{References}

Al-Haj AN, Fulweiler RW (2020) A synthesis of methane emissions from shallow vegetated coastal ecosystems. Glob Change Biol 26:2988-3005. https://doi.org/10.1111/ gcb. 15046

Altor AE, Mitsch WJ (2006) Methane flux from created riparian marshes: relationship to intermittent versus continuous inundation and emergent macrophytes. Ecol Eng 28(3):224-234. https://doi.org/10.1016/j.ecoleng.2006.06. 006

Audet J, Johansen JR, Andersen PM, Baattrup-Pedersen A, Brask-Jensen KM, Elsgaard L, Hoffmann CC (2013) Methane emissions in Danish riparian wetlands: ecosystem comparison and pursuit of vegetation indexes as predictive tools. Ecol Ind 34:548-559. https://doi.org/10.1016/j. ecolind.2013.06.016
Bernal B, Megonigal JP, Mozdzer TJ (2016) An invasive wetland grass primes deep soil carbon pools. Glob Change Biol 23(5):2104-2116. https://doi.org/10.1111/gcb.13539

Bhullar GS, Edwards PJ, Venterink HO (2014) Influence of different plant species on methane emissions from soil in a restored swiss Wetland. PLoS ONE. https://doi.org/10. 1371/journal.pone.0089588

Broome SW, Mendelssohn IA, McKee KL (1995) Relative growth of Spartina patens (Ait.) Muhl. and Scirpus olneyi gray occurring in a mixed stand as affected by salinity and flooding depth. Wetlands 15:20-30. https://doi.org/10. 1007/BF03160676

Bubier JL, Moore TR, Bellisario L, Comer NT, Crill PM (1995) Ecological controls on methane emissions from a Northern Peatland Complex in the zone of discontinuous permafrost, Manitoba Canada. Global Biogeochem Cycle 9(4):455-470. https://doi.org/10.1029/95gb02379

Buffington KJ, Dugger BD, Thorne KM, Takekawa JY (2016) Statistical correction of lidar-derived digital elevation models with multispectral airborne imagery in tidal marshes. Remote Sens Environ 186:616-625

Byrd KB, Ballanti L, Thomas N, Nguyen D, Holmquist JR, Simard M, Windham-Myers L (2018) A remote sensingbased model of tidal marsh aboveground carbon stocks for the conterminous United States. ISPRS J Photogramm Remote Sens 139:255-271

Calhoun A, King GM (1997) Regulation of root-associated methanotrophy by oxygen availability in the rhizosphere of two aquatic macrophytes. Appl Environ Microbiol 63(8):3051-3058. https://doi.org/10.1128/aem.63.8.30513058.1997

Canfield DE (2004) The evolution of the earth surface sulfur reservoir. Am J Sci 304:839-861. https://doi.org/10.2475/ ajs.304.10.839

Chmura GL, Anisfeld SC, Cahoon DR, Lynch JC (2003) Global carbon sequestration in tidal, saline wetland soils. Glob Biogeochem Cycles 17:1111. https://doi.org/10.1029/ 2002GB001917

Colmer TD (2003) Long-distance transport of gases in plants: A perspective on internal aeration and radial oxygen loss from roots. Plant, Cell Environ 26(1):17-36. https://doi. org/10.1046/j.1365-3040.2003.00846.x

Couwenberg J, Thiele A, Tanneberger F, Augustin J, Bärisch S, Dubovik D, Liashchynskaya N, Michaelis D, Minke M, Skuratovich A, Joosten H (2011) Assessing greenhouse gas emissions from peatlands using vegetation as a proxy. Hydrobiologia 674(1):67-89. https://doi.org/10.1007/ s10750-011-0729-x

Crooks S, Herr D, Tamelander J, et al (2011) Mitigating climate change through restoration and management of coastal wetlands and near-shore marine ecosystems: challenges and opportunities.

Derby, K (2016) Methane emissions from a tidal brackish marsh on Maryland's eastern shore and the factors impacting them. Master's Thesis, University of Maryland. Drum https://doi.org/10.13016/M2PV6R

Dias AT, Hoorens B, Logtestijn RS, Vermaat JE, Aerts R (2010) Plant species composition can be used as a proxy to predict methane emissions in peatland ecosystems after land-use changes. Ecosystems 13(4):526-538. https://doi.org/10. 1007/s10021-010-9338-1 
Ding W, Cai Z, Tsuruta H (2005) Plant species effects on methane emissions from freshwater marshes. Atmos Environ 39(18):3199-3207. https://doi.org/10.1016/j. atmosenv.2005.02.022

Ding W, Zhang Y, Cai Z (2010) Impact of permanent inundation on methane emissions from a Spartina alterniflora coastal salt marsh. Atmos Environ 44(32):3894-3900. https://doi. org/10.1016/j.atmosenv.2010.07.025

Emery H, Fulweiler W (2014) Spartina alterniflora and invasive Phragmites australis stands have similar greenhouse gas emissions in a New England marsh. Aquat Bot. https://doi. org/10.1016/j.aquabot.2014.01.010

Emery HE, Fulweiler RW (2017) Incomplete tidal restoration may lead to persistent high $\mathrm{CH}_{4}$ emission. Ecosphere 8(12):e01968. https://doi.org/10.1002/ecs2.1968

Emmer IM, Unger M von, Needelman B, Crooks, S, EmmettMattox, S (2015) Coastal Blue Carbon in Practice: A Manual for Using the VCS Methodology for Tidal Wetland and Seagrass Restoration. Restore America's Estuaries, Arlington, VA., v. 1, p 82. https://www.estuaries.org/ images/rae_coastal_blue_carbon_methodology_web.pdf

Emmer IM, von Unger MBA, Cooks NS, S. Emmett-Mattox. 2015. Coastal blue carbon in practice: a manual for using the vcs methodology for tidal Wetland and Seagrass Restoration

Emmer IM, Needelman BA, Emmett-Mattox S, Crooks S, Megonigal JP, Myers D, Oreska MPJ, McGlathery KJ (2020a) Estimation of baseline carbon stock changes and greenhouse gas emissions in Tidal Wetland restoration and conservation Project Activities (BL-TW). VCS Module VMD0050, v 1.0. Verra (Verified Carbon Standard): Washington, D.C

Emmer IM, Needelman BA, Emmett-Mattox S, Crooks S, Megonigal JP, Myers D, Oreska MPJ, McGlathery KJ (2020b) Methods for monitoring of carbon stock changes and greenhouse gas emissions and removals in Tidal Wetland restoration and conservation project activities (MTW). VCS Module VMD0051, v 1.0, Verra (Verified Carbon Standard): Washington, DC

Epp MA, Chanton JP (1993) Rhizospheric methane oxidation determined via the methyl fluoride inhibition technique. J Geophys Res Atmos 98(D10):18413-18422. https://doi. org/10.1029/93jd01667

Feagin RA, Forbrich I, Huff TP, Barr JG, Ruiz-Plancarte J, Fuentes JD, Najjar RG, Vargas R, Vázquez-Lule A, Windham-Myers L, Kroeger KD, Ward EJ, Moore GW, Leclerc M, Krauss KW, Stagg CL, Alber M, Knox SH, Schäfer KVR, Bianchi TS, Hutchings JA, Nahrawi H, Noormets A, Mitra B, Jaimes A, Hinson AL, Bergamaschi B, King JS, Miao G (2020) Tidal Wetland gross primary production across the continental United States, 2000-2019. Global Biogeochemical Cycles 34

Fisher MM, Reddy KR, DeLaune RD et al (2013) Soil pore water sampling methods. In: DeLaune RD, Reddy KR, Richardson CJ, Megonigal JP (eds) Methods in biogeochemistry of wetlands, vol 10, SSSA Book Series. Soil Science Society of America, Madison, WI

Garcia J-L, Patel BKC, Ollivier B (2000) Taxonomic, phylogenetic, and ecological diversity of methanogenic archaea. Anaerobe 6:205-226. https://doi.org/10.1006/anae.2000. 0345
Gilbert B, Frenzel P (1995) Methanotrophic bacteria in the rhizosphere of rice microcosms and their effect on porewater methane concentration and methane emission. Biol Fertil Soils 20(2):93-100. https://doi.org/10.1007/ bf00336586

Grünfeld S, Brix H (1999) Methanogenesis and methane emissions: effects of water table, substrate type and presence of Phragmites australis. Aquat Bot 64(1):63-75. https://doi. org/10.1016/s0304-3770(99)00010-8

Holm GO, Perez BC, McWhorter DE et al (2016) Ecosystem level methane fluxes from tidal freshwater and brackish marshes of the mississippi river delta: implications for coastal wetland carbon projects. Wetlands. https://doi.org/ 10.1007/s13157-016-0746-7

Holmquist J, Windham-Myers L, Bernal B, Byrd KB, Crooks S, Gonneea ME, Herold N, Knox SH, Kroeger K, McCombs J, Megonigal JP, Meng L, Morris JT, Sutton-Grier AE, Troxler TG, Weller D (2018) Uncertainty in United States coastal wetland greenhouse gas inventorying. Environ Res Lett 13:115005. https://doi.org/10.1088/1748-9326/ aae 157

Holmquist JR, Schile-Beers L, Buffington K, Lu M et al (2021) Scalability and performance tradeoffs in quantifying relationships between elevation and tidal wetland plant communities. Mar Ecol Prog Ser 666:57-72. https://doi.org/10. 3354/meps 13683

Jespersen DN, Sorrell BK, Brix H (1998) Growth and root oxygen release by Typha latifolia and its effects on sediment methanogenesis. Aquat Bot 61(13):165-180. https:// doi.org/10.1016/s0304-3770(98)00071-0

Jordan TE, Correll ADL (1985) Nutrient chemistry and hydrology of interstitial water in brackish tidal marshes of Chesapeake Bay. Estuar Coast Shelf Sci 21(1):45-55

Keller JK, Wolf AA, Weisenhorn PB et al (2009) Elevated $\mathrm{CO}_{2}$ affects porewater chemistry in a brackish marsh. Biogeochemistry 96:101-117. https://doi.org/10.1007/s10533009-9347-3

King GM (1996) In situ analyses of methane oxidation associated with the roots and rhizomes of a bur reed, sparganium eurycarpum, in a Maine Wetland. Appl Environ Microbiol 62:4548-4555. https://doi.org/10.1128/aem.62.12.45484555.1996

Koch MS, Mendelssohn IA, McKee KL (1990) Mechanism for the hydrogen sulfide- induced growth limitation in wetland macrophytes. Limnol Oceanogr 35:399-408. https://doi. org/10.4319/lo.1990.35.2.0399

Koebsch F, Glatzel S, Jurasinski G (2013) Vegetation controls methane emissions in a coastal brackish fen. Wetl Ecol Manag 21:323-337. https://doi.org/10.1007/s11273-0139304-8

Komiya S, Yazaki T, Kondo F, Katano K, Lavric JV, Mctaggart I, Pakoktom T, Siangliw M, Toojinda T, Noborio K (2020) Stable carbon isotope studies of $\mathrm{CH} 4$ dynamics via water and plant pathways in a tropical thai paddy: insights into diel CH 4 transportation. J Geophys Res Biogeosci 125:9. https://doi.org/10.1029/2019jg005112

Le Mer J, Roger P (2001) Production, oxidation, emission and consumption of methane by soils: a review. Eur J Soil Biol 37(1):25-50. 5563(01)01067-6 
Lombardi AE, Epp MA, Chanton JP (1997) Investigation of the methyl fluoride technique for determining rhizospheric methane oxidation. Biogeochemistry 36:153-172

Marsh AS, Rasse DP, Drake BG, Megonigal JP (2005) Effect of elevated $\mathrm{CO}_{2}$ on carbon pools and fluxes in a brackish marsh. Estuaries 28:694-704

Megonigal JP, Guenther AB (2008) Methane emissions from upland forest soils and vegetation. Tree Physiol 28:491-498. https://doi.org/10.1093/treephys/28.4.491

Megonigal JP, Hines ME, Visscher PT (2004) Anaerobic metabolism: linkages to trace gases and aerobic processes. In: Schlesinger WH (ed) Biogeochemistry. Elsevier-Pergamon, Oxford, pp 317-424

Megonigal JP, Schlesinger WH (2002) Methane-limited methanotrophy in tidal freshwater swamps. Glob Biogeochem Cycles 16:1088. https://doi.org/10.1029/ 2001GB001594

Moor H, Rydin H, Hylander K, Nilsson MB, Lindborg R, Norberg J (2017) Towards a trait-based ecology of wetland vegetation. J Ecol 105:1623-1635. https://doi.org/10.1111/ 1365-2745.1273

Mueller P, Hager RN, Meschter JE, Mozdzer TJ, Langley JA, Jensen K, Megonigal JP (2016) Complex invader-ecosystem interactions and seasonality mediate the impact of nonnative Phragmites on $\mathrm{CH}_{4}$ emissions. Biol Invasions 18:2635-2647. https://doi.org/10.1007/s10530-016-10936

Mueller P, Mozdzer TJ, Langley JA, Aoki LR, Noyce GL, Megonigal JP (2020) Plant species determine tidal wetland $\mathrm{CH}_{4}$ response to sea level rise. Nat Commun. https://doi. org/10.1038/s41467-020-18763-4

Nahlik, A., Fennessy, M. Carbon storage in US wetlands (2016) Nat Commun 7:13835. https://doi.org/10.1038/ ncomms 13835

Needelman BA, Emmer IM, Emmett-Mattox S, Crooks S, Megonigal JP, Myers D, Oreska MPJ, McGlathery K (2018) The science and policy of the verified carbon standard methodology for tidal wetland and seagrass restoration. Estuaries Coasts 41(8):2159-2171. https://doi. org/10.1007/s12237-018-0429-0

Neubauer SC, Givler K, Valentine S, Megonigal JP (2005) Seasonal patterns and plant-mediated controls of subsurface wetland biogeochemistry. Ecology 86(12):3334-3344. https://doi.org/10.1890/04-1951

Neubauer SC, Megonigal JP (2015) Moving beyond global warming potentials to quantify the climatic role of. Ecosystems. https://doi.org/10.1007/s10021-015-9879-4

Noyce GL, Megonigal JP (2021) Biogeochemical and plant trait mechanisms drive enhanced methane emissions in response to whole-ecosystem warming. Biogeosciences 18(8):2449-2463. https://doi.org/10.5194/bg-18-24492021

Perry JE, Hershner CH (1999) Temporal changes in the vegetation pattern in a tidal freshwater marsh. Wetlands 19(1):90-99. https://doi.org/10.1007/bf03161737

Pitz SA, Megonigal JP (2017) Temperate forest methane sink diminished by tree emissions. New Phytol 214(4):1432-1439. https://doi.org/10.1111/nph.14559

Poffenbarger HJ, Needelman BA, Megonigal JP (2011) Salinity influence on methane emissions from tidal marshes.
Wetlands 31:831-842. https://doi.org/10.1007/s13157011-0197-0

Purvaja R, Ramesh R (2001) Natural and anthropogenic methane emission from coastal wetlands of South India. Environ Manage 27(4):547-557

Rabenhorst MC, Megonigal JP, Keller JK (2010) Synthetic iron oxides for documenting sulfide in marsh pore water. Soil Sci Soc Am J 74(4):1383-1388. https://doi.org/10.2136/ sssaj2009.0435

Roden E, Wetzel R (2003) Competition between Fe(III)-reducing and methanogenic bacteria for acetate in iron-rich freshwater sediments. Microb Ecol 45(3):252-258. https:// doi.org/10.1007/s00248-002-1037-9

Saunois et al (2020) The global methane budget 2000-2017. Earth Syst Sci Data 12:1561-1623. https://doi.org/10. 5194/essd-12-1561-2020

Solomon S, Qin D, Manning M et al (2007) IPCC fourth assessment report (AR4). Retrieved 4:2011

Sorrell BK, Brix H, DeLaune RD, et al (2013) Gas transport and exchange through Wetland Plant Aerenchyma. In: SSSA Book Series. Soil science society of America

Sorrell B, Mendelssohn IA, McKee KL, Woods RA (2000) Ecophysiology of Wetland plant roots: a modelling comparison of aeration in relation to species distribution. Ann Bot 86(3):675-685. https://doi.org/10.1006/anbo.2000. 1173

Sutton-Grier AE, Megonigal JP (2011) Plant species traits regulate methane production in freshwater wetland soils. Soil Biol Biochem 43:413-420. https://doi.org/10.1016/j. soilbio.2010.11.009

Tuxen K, Schile L, Stralberg D et al (2011) Mapping changes in tidal wetland vegetation composition and pattern across a salinity gradient using high spatial resolution imagery. Wetlands Ecol Manage 19:141-157. https://doi.org/10. 1007/s11273-010-9207-x

Vann CD, Megonigal JP (2003) Elevated $\mathrm{CO}_{2}$ and water depth regulation of methane emissions: Comparison of woody and non-woody wetland plant species. Biogeochemistry 63:117-134. https://doi.org/10.1023/A:1023397032331

Villa JA, Ju Y, Stephen T, Rey-Sanchez C, Wrighton KC, Bohrer G (2020) Plant-mediated methane transport in emergent and floating-leaved species of a temperate freshwater mineral-soil wetland. Limnol Oceanogr 65(7):1635-1650. https://doi.org/10.1002/lno.11467

Walker DA, Auerbach NA, Bockheim JG et al (1998) Energy and trace-gas fluxes across a soil $\mathrm{pH}$ boundary in the Arctic. Nature 394:469-472. https://doi.org/10.1038/28839

Wang Z, Zeng D Jr, WHP (1996) Methane emissions from natural wetlands. Environ Monit Assess 42:143-161. https://doi.org/10.1007/BF00394047

Weiss JV, Emerson D, Backer SM, Megonigal JP (2003) Enumeration of $\mathrm{Fe}(\mathrm{II})$-oxidizing and $\mathrm{Fe}$ (III)-reducing bacteria in the root zone of wetland plants: implications for a rhizosphere iron cycle. Biogeochemistry 64:77-96

Weiss JV, Emerson D, Megonigal JP (2004) Geochemical control of microbial Fe(III) reduction potential in wetlands: Comparison of the rhizosphere to non-rhizosphere soil. FEMS Microbiol Ecol 48(1):89-100. https://doi.org/10. 1016/j.femsec.2003.12.014 
Whalen SC (2005) Biogeochemistry of methane exchange between natural wetlands and the atmosphere. Environ Eng Sci 22:73-94

Windham L (2001) Comparison of biomass production and decomposition between Phragmites australis (common reed) and Spartina patens (salt hay grass) in brackish tidal marshes of New Jersey, USA. Wetlands 21:179-188. https://doi.org/10.1672/0277-5212(2001)021[0179: COBPAD]2.0.CO;2

Yu K, Hiscox A, DeLaune RD et al (2013) Greenhouse gas emission by static chamber and eddy flux methods. In: DeLaune RD, Reddy KR, Richardson CJ, Megonigal JP (eds) Methods in biogeochemistry of wetlands, vol 10,
SSSA Book Series. Soil Science Society of America, Madison, WI

Yuan J, Ding W, Liu D, Kang H, Freeman C, Xiang J, Lin Y (2015) Exotic Spartina alterniflora invasion alters ecosystem-atmosphere exchange of $\mathrm{CH}_{4}$ and $\mathrm{N}_{2} \mathrm{O}$ and carbon sequestration in a coastal salt marsh in China. Glob Chang Biol 21(4):1567-1580. https://doi.org/10.1111/gcb.12797

Publisher's Note Springer Nature remains neutral with regard to jurisdictional claims in published maps and institutional affiliations. 